\title{
SOME OBSERVATIONS ON THE SHORE FAUNA OF BAFFIN ISLAND
}

\author{
D. V. Ellis*
}

$\mathbf{T}$ TнE first trained biologist to examine the shores of Baffin Island was Ludwig Kumlien who was a member of the Howgate Polar expedition 1877-8 which wintered in Cumberland Sound (Kumlien, 1879). Previous to his report at least one collection was known, for Hancock (1846) describes a series of shells brought back from Cumberland Sound by "Messrs. Warham and Harrison, masters of whaling vessels belonging to the port of Newcastle". The German polar expedition of 1882-3 also visited Cumberland Sound and the expedition's doctor, W. Schliephake, collected a few shelled animals (Pfeffer, 1886). Most of the specimens from these last two collections were not from the shore but from shallow water and frequently the exact site was not recorded.

So far this century there are reports from six expeditions. Occasional marine biological collections were made by the Neptune expedition of 1903-5 to the eastern Arctic (Dall, 1924). The reports of the Fifth Thule expedition, 1921-4 also contain scattered records and the Godtbaab expedition in 1928 took shore and offshore animals from Totnes Road, Exeter Sound (Riis-Carstensen, 1931). In $1948 \mathrm{E}$, Grainger brought back some intertidal animals from Frobisher Bay. However, the two most recent collections were those made in 1951 and 1952 by the Calanus expeditions, organized by the Fisheries Research Board of Canada.

From the published reports and a preliminary examination of the Calanus shore collections, it seemed probable that the intertidal fauna north of Cumberland Sound differed from that within the sound. The intertidal fauna of the nearby coasts of Greenland is fairly well known, Madsen having described a transition in the intertidal fauna north of Angmagssalik in east Greenland (1936, p. 49) and a similar transition on the west Greenland coast near Upernavik (1940, pp. 7-8). Knowledge of the shore fauna of Cumberland Sound and Totnes Road indicated that the intertidal transition in Baffin Island might be similar to that in Greenland.

From June to September 1953, V. C. Wynne-Edwards and the writer visited Frobisher Bay, Pangnirtung, and several other settlements on the east coast of Baffin Island, collecting shore animals and studying the intertidal environment. The shore or intertidal zone was regarded as the region between high and low tidal levels, and animals collected on the shore by hand or hand net are counted as intertidal animals. The terms "littoral", "infralittoral", etc.

*Department of Zoology, McGill University. 


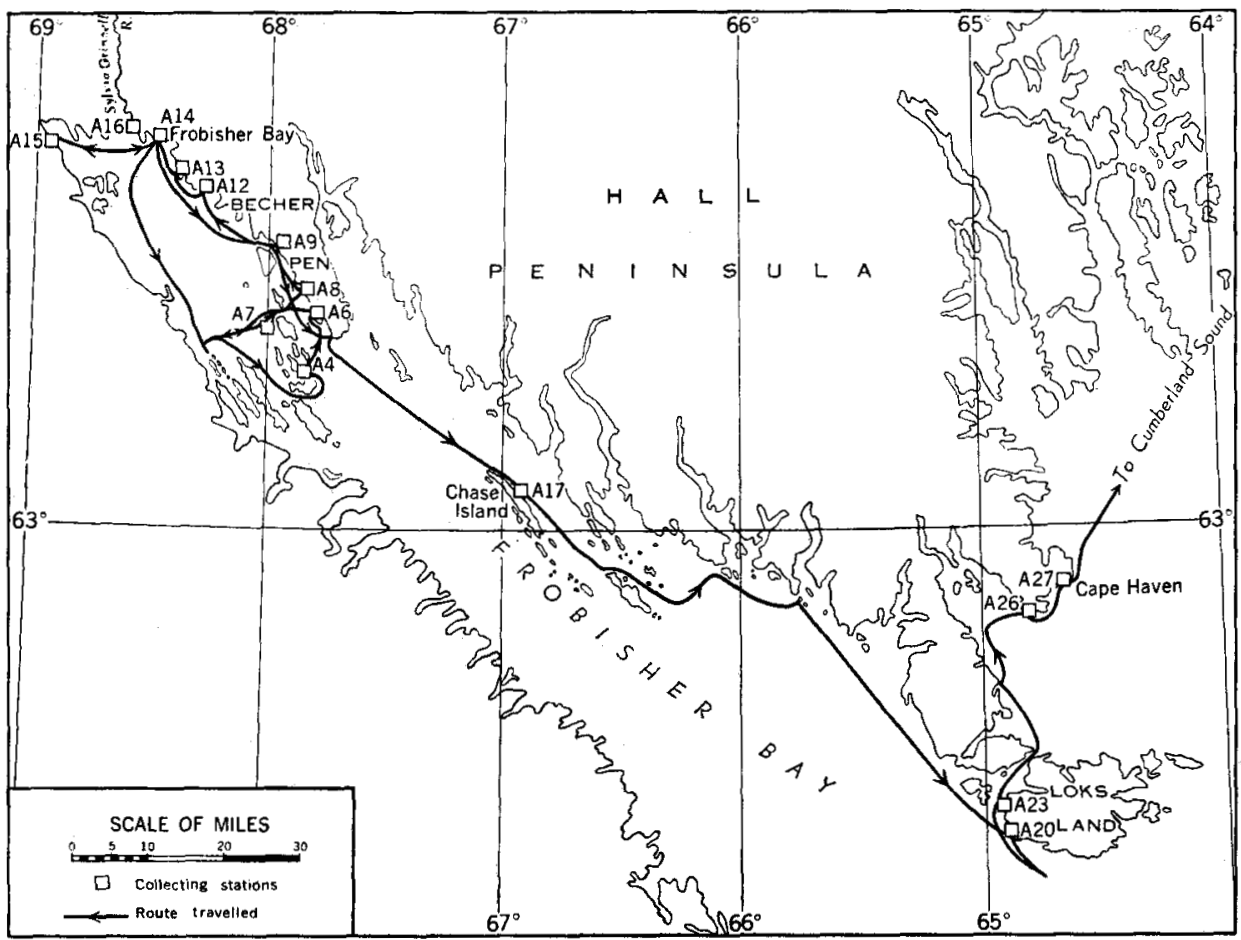

Fig. 1. Collecting stations, Frobisher Bay.

defined by Stephenson and Stephenson (1949, p. 298) are not used in this preliminary study of the shore fauna. We collected from both the north and the south of the expected transition region. The collecting stations are listed in Table 1 and are shown in Figures 1, 2, and 3. Collections were made by hand, supplemented with a hand sieve on sandy shores, and a hand net for fishing in rock-pools. In addition specimens were obtained from a depth of two fathoms or less (i.e. the immediate shallow-water zone) by a small dredge operated from a dinghy in Frobisher Bay, and from a whale boat near Padloping Island.

The Royal Canadian Air Force took me to Frobisher Bay, where I arrived on June 6. I spent the following six weeks travelling round the head of the bay by sled and after break-up by dinghy, during which time ten collections were made. Wynne-Edwards arrived at Frobisher Bay in late July, and on the 24th we set out for Pangnirtung in the Hudson's Bay Company's Peterhead boat Nanook 11. Additional collections were made in Frobisher Bay and near Cape Haven (Fig. 1). Pack ice and bad weather prevented observations near the entrance to Cumberland Sound, but one collection was made at Miliakdjuin Island (Fig. 2). Nine collections were made in Cumberland Sound, including a second visit to Miliakdjuin Island with the Royal Canadian Mounted Police in their Peterhead boat. A collection was also made at the head of Pangnirtung Fiord by H. R. Thompson, a member of the Arctic Institute's 1953 expedition 


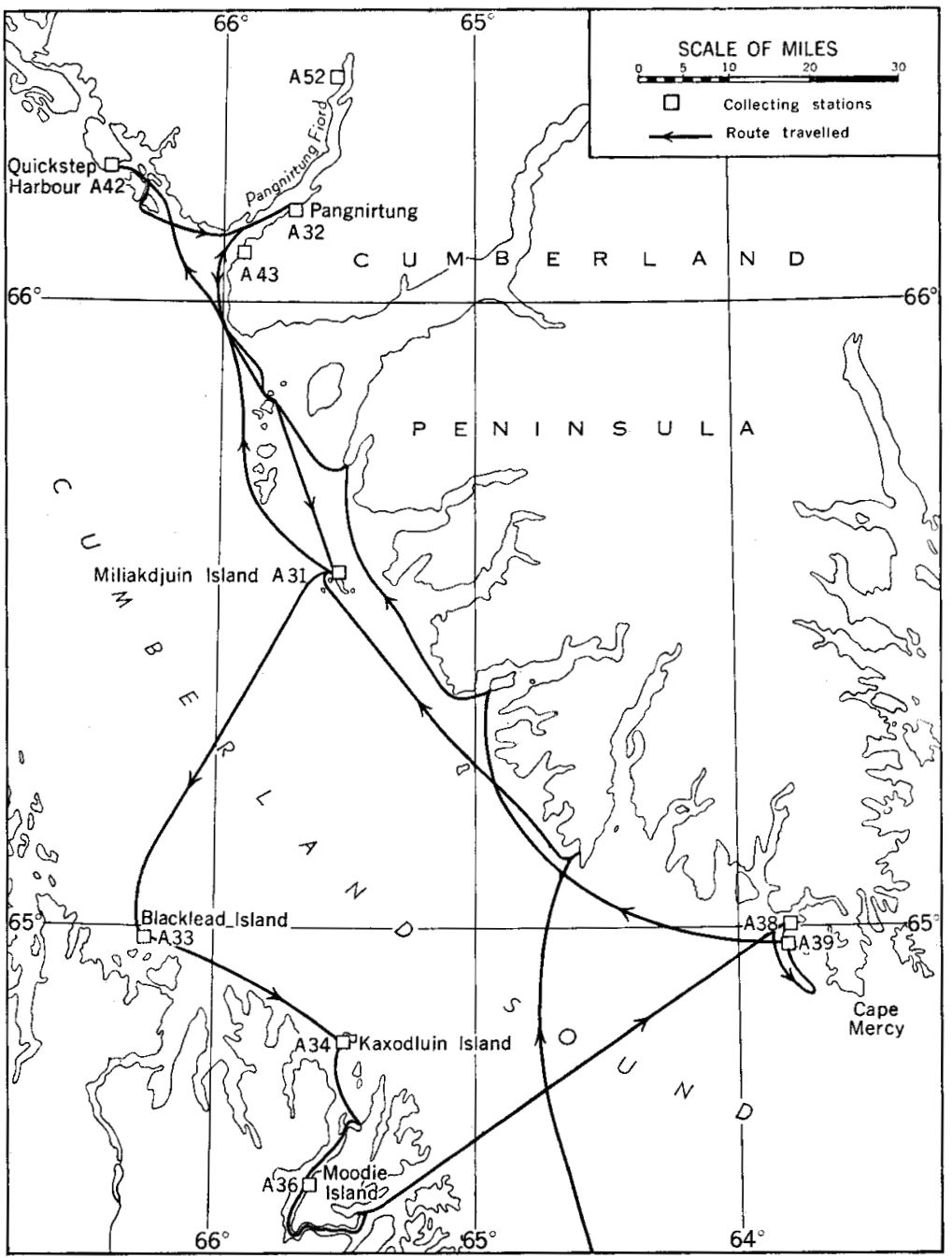

Fig. 2. Collecting stations, Cumberland Sound.

to Baffin Island. On August 13 an R.C.A.F. aircraft took me to Padloping Island, just north of the Cumberland Peninsula, and travelling thence by whaleboat, I made five collections (Fig. 3). On Angust 26, I boarded the C. D. Howe going north on her annual supply voyage, and made brief collections at Pond Inlet, Craig Harbour, and Clyde River before returning to the south.

\section{The Baffin Island collections}

The more common species found in 1953 are listed in Table 2, while Table 3 summarizes the present known distribution of the intertidal fauna of Baffin Island. These tables show that the shore fauna in Frobisher Bay is similar to that in Cumberland Sound. North of Cumberland Sound there is a change in the abundance and the variety of shore fauna, and in the vicinity of Padloping Island and farther north the intertidal zone is almost barren. 
Fig. 3.

Collecting stations, Padloping Island.

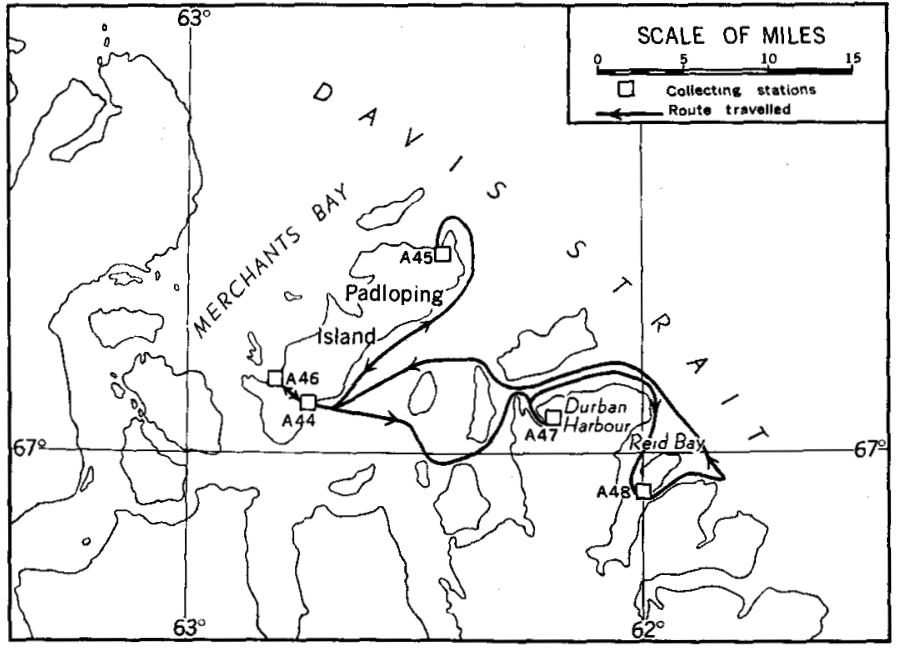

Table 1. Collecting stations, 1953.

\begin{tabular}{|c|c|c|}
\hline Station & Date & Locality \\
\hline $\begin{array}{l}\text { A4 } \\
\text { A6 } \\
\text { A7 } \\
\text { A8 } \\
\text { A9 } \\
\text { A12 } \\
\text { A13 } \\
\text { A14 } \\
\text { A15 } \\
\text { A16 } \\
\text { A17 } \\
\text { A20 } \\
\text { A23 }\end{array}$ & $\begin{array}{l}\text { June } 16-18 \\
\text { June } 19-21 \\
\text { June } 22 \\
\text { June } 26-\text { July } 1 \\
\text { July } 1-4 \\
\text { July } 4 \\
\text { July } 5 \\
\text { July } 6-24 \\
\text { July } 13 \\
\text { July } 21 \\
\text { July } 25 \\
\text { July } 26 \\
\text { July } 27\end{array}$ & $\begin{array}{l}\text { Frobisher Bay } \\
\text { Island west of Becher Peninsula } \\
\text { Becher Peninsula } \\
\text { Island west of Becher Peninsula } \\
\text { Becher Peninsula } \\
\text { Becher Peninsula } \\
\text { Between Becher Peninsula and Frobisher Bay (settlement) } \\
\text { Between Becher Peninsula and Frobisher Bay (settlement) } \\
\text { Frobisher Bay (settlement) } \\
\text { West of Frobisher Bay (settlement) } \\
\text { Mouth of Sylvia Grinnell River } \\
\text { Chase Island } \\
\text { Loks Land } \\
\text { Loks Land }\end{array}$ \\
\hline $\begin{array}{l}\text { A26 } \\
\text { A27 }\end{array}$ & $\begin{array}{l}\text { July } 28 \\
\text { July } 29 \text {-August } 1\end{array}$ & $\begin{array}{l}\text { Frobisher Bay-Cumberland Sound } \\
\text { Southwest of Cape Haven } \\
\text { West of Cape Haven }\end{array}$ \\
\hline $\begin{array}{l}\text { A31 } \\
\text { A32 }\end{array}$ & $\begin{array}{l}\text { August } 385 \\
\text { August } 4-5 \\
\text { August } 11-13\end{array}$ & $\begin{array}{l}\text { Cumberland Sound } \\
\text { Miliakdjuin Island } \\
\text { Pangnirtung }\end{array}$ \\
\hline $\begin{array}{l}\text { A33 } \\
\text { A34 } \\
\text { A36 } \\
\text { A38 } \\
\text { A39 } \\
\text { A42 } \\
\text { A43 } \\
\text { A5 }\end{array}$ & $\begin{array}{l}\text { August } 6 \\
\text { August } 6 \\
\text { August } 7 \\
\text { August } 8 \\
\text { August } 8 \\
\text { August } 10 \\
\text { August } 11 \\
\text { August } 25\end{array}$ & $\begin{array}{l}\text { Blacklead Island } \\
\text { Kaxodluin Island } \\
\text { Moodie Island } \\
\text { West of Cape Mercy } \\
\text { West of Cape Mercy } \\
\text { Quickstep Harbour } \\
\text { Mouth of Pangnirtung Fiord } \\
\text { Near head of Pangnirtung Fiord (Collection by H. R. Thompson) }\end{array}$ \\
\hline & & Padloping Island \\
\hline $\begin{array}{l}\text { A44 } \\
\text { A45 } \\
\text { A46 } \\
\text { A47 } \\
\text { A48 } \\
\text { A49 } \\
\text { A50 } \\
\text { A } 51\end{array}$ & $\begin{array}{l}\text { August } 14-26 \\
\text { August } 15 \\
\text { August } 17 \\
\text { August } 19 \\
\text { August } 20 \\
\text { August } 27 \\
\text { August } 29 \\
\text { September } 2\end{array}$ & $\begin{array}{l}\text { Padloping Island (settlement) } \\
\text { Northern tip of Padloping Island } \\
\text { Southwest Padloping Island } \\
\text { Durban Harbour } \\
\text { Reid Bay, southern tip of island } \\
\text { Pond Inlet (settlement) } \\
\text { Craig Harbour } \\
\text { Clyde River (settlement) }\end{array}$ \\
\hline
\end{tabular}

\section{The intertidal species of Baffin Island and Greenland}

The intertidal species of Baffin Island and Greenland can be divided arbitrarily into two groups that are a convenient means of expressing two different methods of adaptation to the intertidal environment. The two 


\section{Anthozoa}

Halcampa arclica Carlgren

Bunodactis stella (Verril)

Nemertina

Amphiporus angulatus (Fabr.)

Ectoprocta

Gemellaria loricata (L)

Alcyonidium gelatinosum (L.)

Priapulida

Priapulus caudalus (Lamark)

Polychaeta

Harmothoe imbricata (L.)

Eteone longa (Fabr

Scoloplos armiger (Mull.)

Arenicola marina (Fabr.

Cistenides granulata (L.)

Cirripeda

Balanus balanoides (L.)

Amphipoda

Pseudalibrotus littoralis (Kroy.)

Gammarus setosus Dementicva Segerstrale

Gastropoda

Acmaea lestudinalis (Mull.)

Margarita groenlandica (Chem.)

Margarila helicina (Phipps)

Littorina saxatilis (Olivi)
Coryphella salmonacea (Couth)

Coryphella salm

Pelecypoda

Modioluria discors (L.)

Modiolaria faba (

Saxicava arctica (L.)

Saxicava arctica

Soxiciouncala

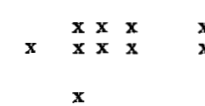

Stephanasterios albula (Stimp)

Stephanasterios albula (Stimp)
Strongylocentrotus droebachiensis (Mull.)

Strongylocen

Ascidia callosa Stimp.

Ascidid

Fish
Myoxocephalus scorpioides (Fabr.)
Myoxocephalus scorpius (L.)

Mnoxocephalus scorpius (L.)

Gymnocanthus tricuspis (Reinhardt)

Table 2. The common intertidal species observed in 1953; $x$-collected, n-not collected, $d-d e a d$ specimen only, ?-identification uncertain. 


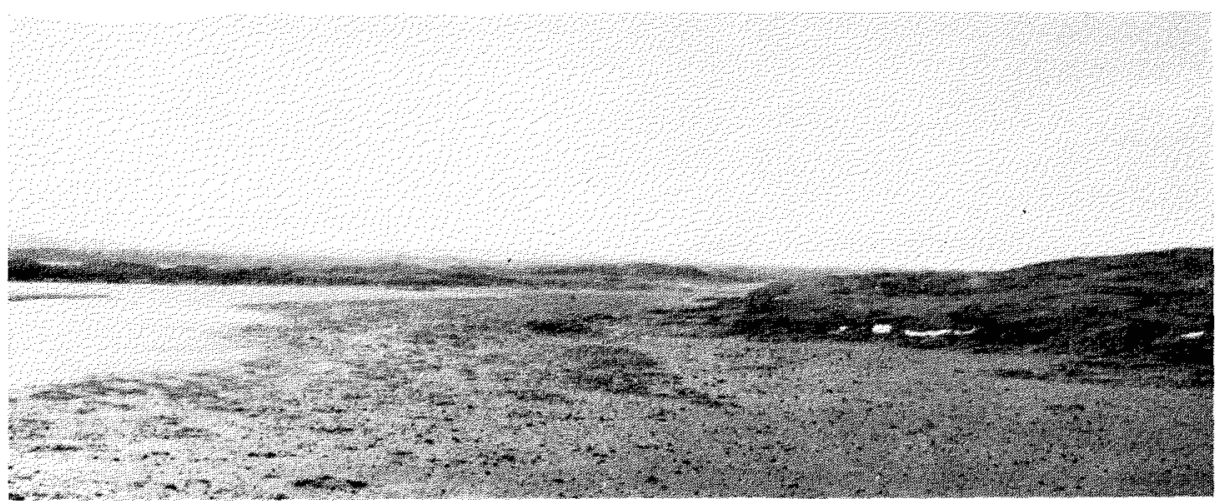

Fig. 4. Station A14, Frobisher at low water showing the wide tidal flat with scattered boulders. Notice the low hilly country in the background associated with the extensive sandy beaches of this region.

groups also have a distinctly different distribution in the arctic and subarctic. One group includes animals that usually live only between tide-marks and normally die when immersed for any length of time; these are specifically intertidal species and include such forms as the barnacle, Balanus balanoides, and the periwinkle, Littorina saxatilis. The other group is comprised of species generally found in shallow water, but which can withstand exposure to the air for short periods, and are able to colonize the lower levels of the shores. They are shallow-water forms that occur incidentally on the shores, and include such species as the clam, Modiolaria discors, and the scale-worm, Harmotboe imbricata. The mussel, Mytilus edulis, and some other species do not fit easily into either of these groups, for they occur both between tide-marks and in shallow water.

Madsen used the intertidal transition in Greenland as the boundary between marine arctic and subarctic regions (1936, p. 65). He shows that the intertidal transition on the east coast of Greenland is independent of changes in climate and tidal amplitude. He postulates that it is caused by the mixing of two oceanic currents, the warm Irminger current and the cold East Greenland Polar current. Dunbar (1951) based on Smith, Soule, and Mosby (1937) and on Kiilerich (1939) has shown that marine conditions off west Greenland and at the southeast tip of Baffin Island are similar to those off southeast Greenland, for Atlantic influence has been traced in the water of all three regions. The east coast of Baffin Island can be similarly divided into marine arctic and subarctic regions. Dunbar defines arctic marine areas as "composed of arctic water only, that is to say of water originating from the upper 200 metres of the polar basin; subarctic areas as composed of a mixture of arctic and non arctic water" (1951, pp. 109-10). Dunbar's definition is used in this paper. The terms "high arctic" and "low arctic" used by many European biologists (Lemche, 1941; Ekman, 1953, etc.) to subdivide the arctic region are not used here, and the term "panarctic" refers to species inhabiting both arctic and subarctic regions. 
Table 3. The present known distribution of the commonest shore animals in Baffin Island, based on previous collections (o) and those made in 1953 ( $x$ ).

\begin{tabular}{|c|c|c|c|}
\hline $\begin{array}{l}\text { Species } \\
\text { Anthozoa } \\
\text { H. arctica } \\
\text { B. stella }\end{array}$ & $\begin{array}{c}\text { Frobisher Bay } \\
\qquad \begin{array}{c}\mathbf{x} \\
\mathbf{x}\end{array}\end{array}$ & $\begin{array}{c}\text { Cumberland Sound } \\
\text { × } \\
\text { xo }\end{array}$ & North of Cumberland Sound \\
\hline $\begin{array}{l}\text { Nemertina } \\
\text { A. angulatus }\end{array}$ & $x$ & 0 & \\
\hline $\begin{array}{l}\text { Ectoprocta } \\
\text { G. loricata } \\
\text { A. gelatinosum }\end{array}$ & $\begin{array}{l}x \\
x\end{array}$ & $\begin{array}{l}\text { xo } \\
\text { xo }\end{array}$ & \\
\hline $\begin{array}{l}\text { Priapulida } \\
P . \text { caudatus }\end{array}$ & $\mathbf{x}$ & xo & \\
\hline $\begin{array}{l}\text { Polychaeta } \\
\text { H. imbricaita } \\
\text { E. Longa } \\
\text { S. armiger } \\
\text { C. copitata } \\
\text { A. marina } \\
\text { C. granulata }\end{array}$ & $\begin{array}{l}\text { xo } \\
\text { xo } \\
\text { xo } \\
\text { x } \\
x\end{array}$ & $\begin{array}{c}0 \\
0 \\
0 \\
0 \\
0 \\
\text { xo }\end{array}$ & $\mathrm{x} 0$ \\
\hline $\begin{array}{l}\text { Cirripeda } \\
\text { B. balanoides }\end{array}$ & $\mathrm{x}$ & xo & \\
\hline $\begin{array}{l}\text { Amphipoda } \\
\text { P. littoralis } \\
\text { G. nugax } \\
\text { G.z. oceanicus } \\
\text { G. setosus }\end{array}$ & $\begin{array}{l}x_{0} \\
x \\
x(0) \\
x 0\end{array}$ & $\begin{array}{c}\text { xo } \\
\text { o } \\
\text { xo } \\
\text { xo }\end{array}$ & $\mathrm{x}$ \\
\hline $\begin{array}{l}\text { Gastropoda } \\
\text { A. testudinalis } \\
\text { M. groenlandica } \\
\text { M. helicina } \\
\text { L. saxatilis } \\
\text { C. salmonacea }\end{array}$ & $\begin{array}{l}x^{1} \\
x_{0} \\
x_{0} \\
x^{1}\end{array}$ & $\begin{array}{l}\text { xo } \\
\text { xo } \\
\text { xo } \\
\text { xo } \\
\text { xo }\end{array}$ & $\begin{array}{r}0 \\
\text { xo }\end{array}$ \\
\hline $\begin{array}{l}\text { Pelecypoda } \\
\text { M. discors } \\
\text { M. faba } \\
\text { M. edulis } \\
\text { S. arrtica } \\
\text { M. truncata }\end{array}$ & $\begin{array}{l}\mathbf{x} \\
\text { xo } \\
\mathbf{x} \\
\mathbf{x}\end{array}$ & $\begin{array}{l}\text { xo } \\
\text { xo } \\
\text { x } \\
\text { xo } \\
\text { xo }\end{array}$ & $\begin{array}{l}x^{1} \\
\mathbf{x} \\
\mathbf{x} \\
\mathbf{x}\end{array}$ \\
\hline $\begin{array}{l}\text { Echinoderma } \\
\text { S. albula } \\
\text { S. droebachiensis }\end{array}$ & & $\stackrel{\circ}{\circ}$ & \\
\hline $\begin{array}{l}\text { Tunicata } \\
\text { A. callosa }\end{array}$ & $\mathrm{x}$ & xo & \\
\hline $\begin{array}{l}\text { Fjsh } \\
\text { M. scorpioides } \\
\text { M. scorpius } \\
\text { O. quadricornis } \\
\text { G. tricuspis }\end{array}$ & $\mathrm{x}$ & $\begin{array}{l}x_{0} \\
\times \\
0 \\
0\end{array}$ & $\mathrm{x}$ \\
\hline
\end{tabular}

The shore animals of Baffin Island differ from those of Greenland. $M$. edulis is found in shallow water in Baffin Island as far north as Pond Inlet, but has not been found north of the transition in east Greenland. The lug-worm, Arenicola marina, is a rare intertidal species in Baffin Island, whereas it is fairly abundant south of the transition in east and west Greenland (Madsen, 1936, p. 55; Steven, 1939, pp. 59-60). Molluscs were found on the shore at Padloping Island; Madsen states that they do not occur intertidally north of the transition in east Greenland. A barren zone extending to two fathoms below low-water level similar to that along the entire coast of east Greenland, is only found north of Padloping Island in Baffin Island. These differences suggest 


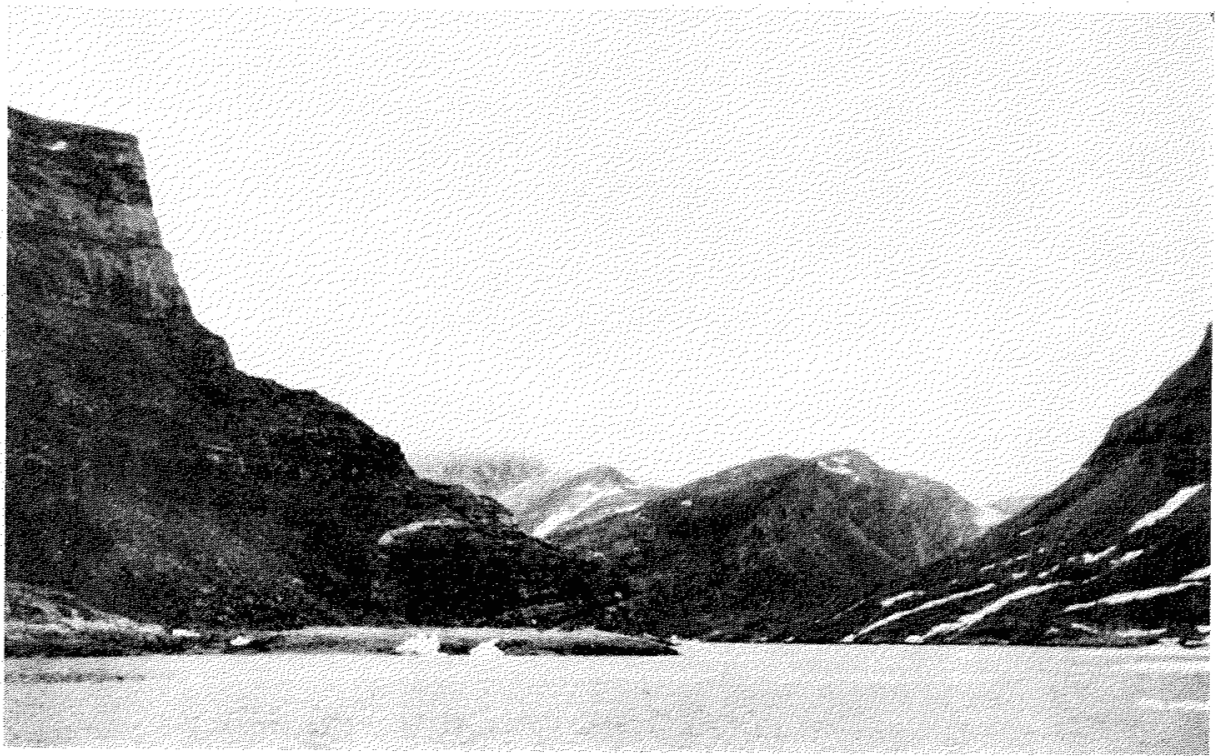

Fig. 5. Beach at the mouth of Cumberland Sound near Station A36. Typical fiord country with steep rocky beaches. High water mark is revealed by white line at left, created by ice scraping off the lichens and algae that would normally grow on the rock.

that Madsen's theory about the shore fauna and the underlying currents does not completely explain the transition in Baffin Island.

\section{Factors affecting the distribution of the shore animals in Baffin Island compared with Greenland}

Among the environmental factors affecting the distribution of shore animals air temperature and precipitation are probably the least significant. Madsen (1936) shows the transition on the east and west coasts of Greenland to be independent of air temperature and precipitation. A comparison of data from Rae (1951) with those from Madsen (1936) shows that the Baffin Island coast is colder and drier than the Greenland coasts at the same latitudes and the transition occurs in regions with different annual mean temperatures and precipitation.

The observed transition was independent of change in the physiography. In the upper parts of Frobisher Bay and Cumberland Sound the coasts are low and hilly with many gently sloping beaches and large tidal flats of sand and mud (Fig. 4). Near the mouths of these two inlets the coast is indented by fiords with steep rocky shores (Fig. 5). On sandy beaches and rocky shores south of the transition the fauna was similar throughout. North of the transition the shore were mainly steep and rocky, and gently sloping beaches were rare, but even where conditions were suitable for intertidal fauna, life was generally absent (Fig. 6).

Stephenson and Stephenson (1954) have described the effects of ice action upon the shore fauna. In Baffin Island ice forming close to the shores 
eventually reaches six or seven feet and may become even thicker if there is much ice movement during the winter. If the thickness of the sea ice is greater than the tidal amplitude, as is common in many parts of the arctic, the entire shore becomes completely covered with ice. However, when the tidal amplitude is large, as in southern Baffin Island ${ }^{1}$ only the upper reaches of the shore freeze solidly, forming an ice foot (Fig. 7). The ice foot is more conspicuous on steep rocky shores than on gently sloping beaches. At low water during winter, ice floating on the surface of the sea close to shore abrades the exposed surfaces below the ice foot. Thus ice on the shore affects the intertidal fauna in two ways. Animals present at the upper levels are generally killed by freezing, and at lower levels they are abraded from the exposed surfaces (Fig. 8). Both freezing and abrasion occur extensively in Cumberland Sound and Frobisher Bay. North of Padloping Island the intertidal zone appeared to freeze almost completely, and abrasion was relatively unimportant. At Padloping Island the entrance to a tidal lagoon was reported by the Eskimo to be comparatively free of ice in winter, and a few intertidal animals were found there (Station A44).

North of Padloping Island the sea-bottom was barren when seen through shallow water, although it was beyond the reach of abrading ice. Thorson (1933, p. 17) suggested that such a barren zone extending from the shore into shallow water was created mainly by a layer of surface water of very low salinity formed during the summer thaw. He called this layer the "fjordwater". Bertelsen (1937, p. 15) named the combined shore and shallow water barren zone the "euryhaline littoral fauna" zone. Most of the species collected in Baffin Island in 1953 are panarctic shallow-water animals that occur only incidentally on the shores. These animals are not found near high water level, where they would be exposed for long periods to air, and they keep below the surface layer of low salinity "fjord-water" wherever it occurs. Thus a barren "euryhaline littoral fauna" zone is formed. This zone was clearly visible north of Padloping Island but was not seen in Cumberland Sound or Frobisher Bay. The specifically intertidal animals such as the periwinkle, L. saxatilis, and the barnacle, B. balanoides, are found in places where there is a well-developed "euryhaline littoral fauna" zone (Bertelsen, 1937, p. 27). Consequently these species are not kept off the shores by "fjord-water" as are the shallow-water species, and the presence of "fjord-water" is not the limiting factor in the distribution of these two species. The distribution of the lug-worm, $A$. marina may be similar, for it is found at Angmagssalik and Pangnirtung but it has not been found north of the transition in either Greenland or Baffin Island. Tolerance of variable salinity is a typical adaptation of intertidal animals and may account for the presence of $B$. balanoides, $L$. saxatilis, and $A$. marina at Angmagssalik in east Greenland where there is a well-developed layer of "fjord-water".

1At Pangnirtung the tidal amplitude varies between sixteen and twenty feet and in Frobisher Bay, between twenty and forty feet. At Padloping Island the neap tide amplitude is about two feet, and the spring tide amplitude about six feet. North of Padloping Island the tidal ranges are not so well known, but appear to be similar to those at Padloping Island (Canada: Hydrog. Service, 1953). 


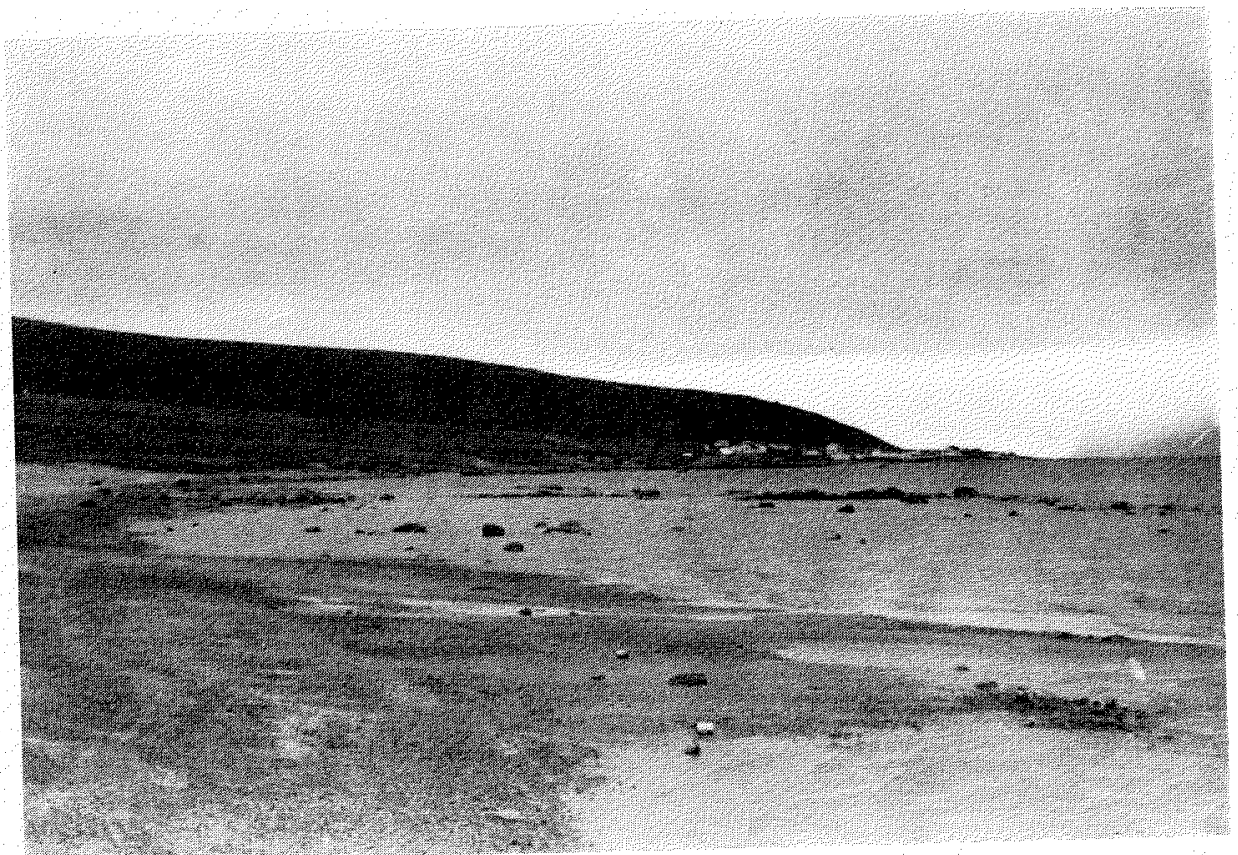

Fig. 6. Near Clyde settlement, Station A51. Low water exposes small tidal flats devoid of life.

Fig. 7. The ice foot in Frobisher Bay. Low water occasionally revealed an ice foot 25 feet thick.

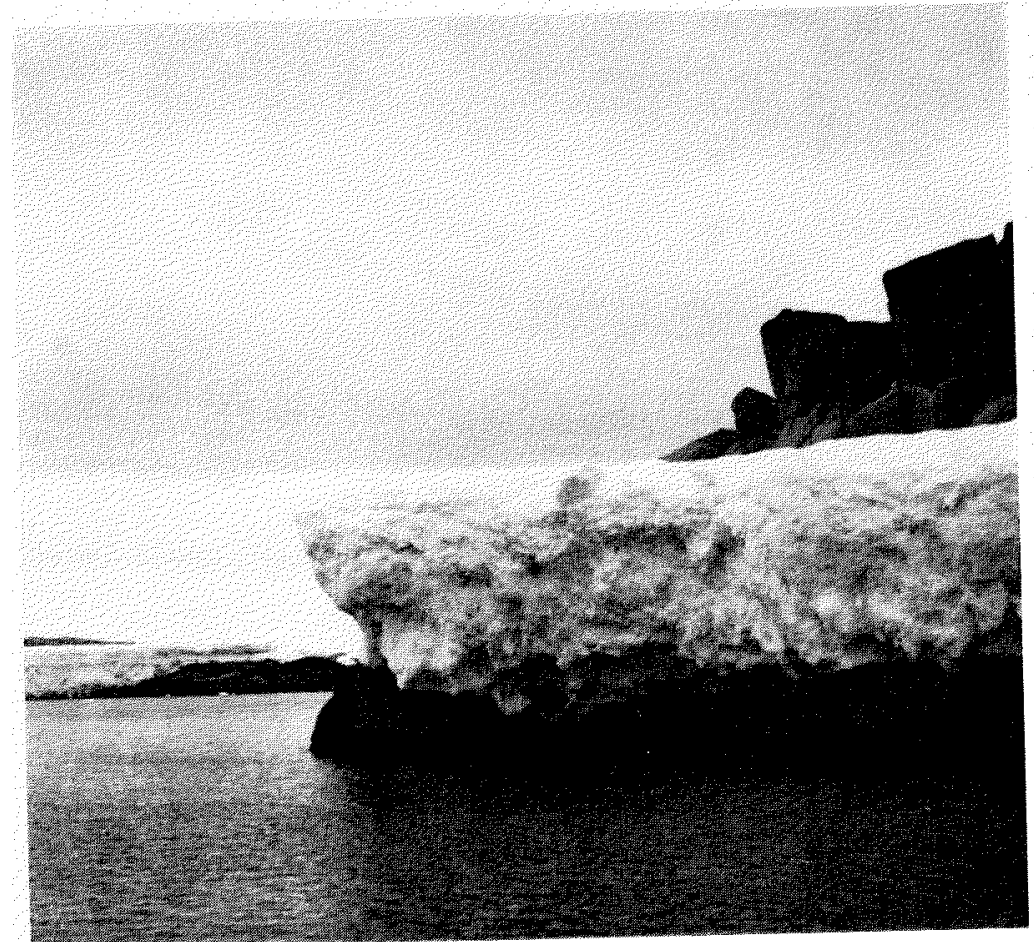




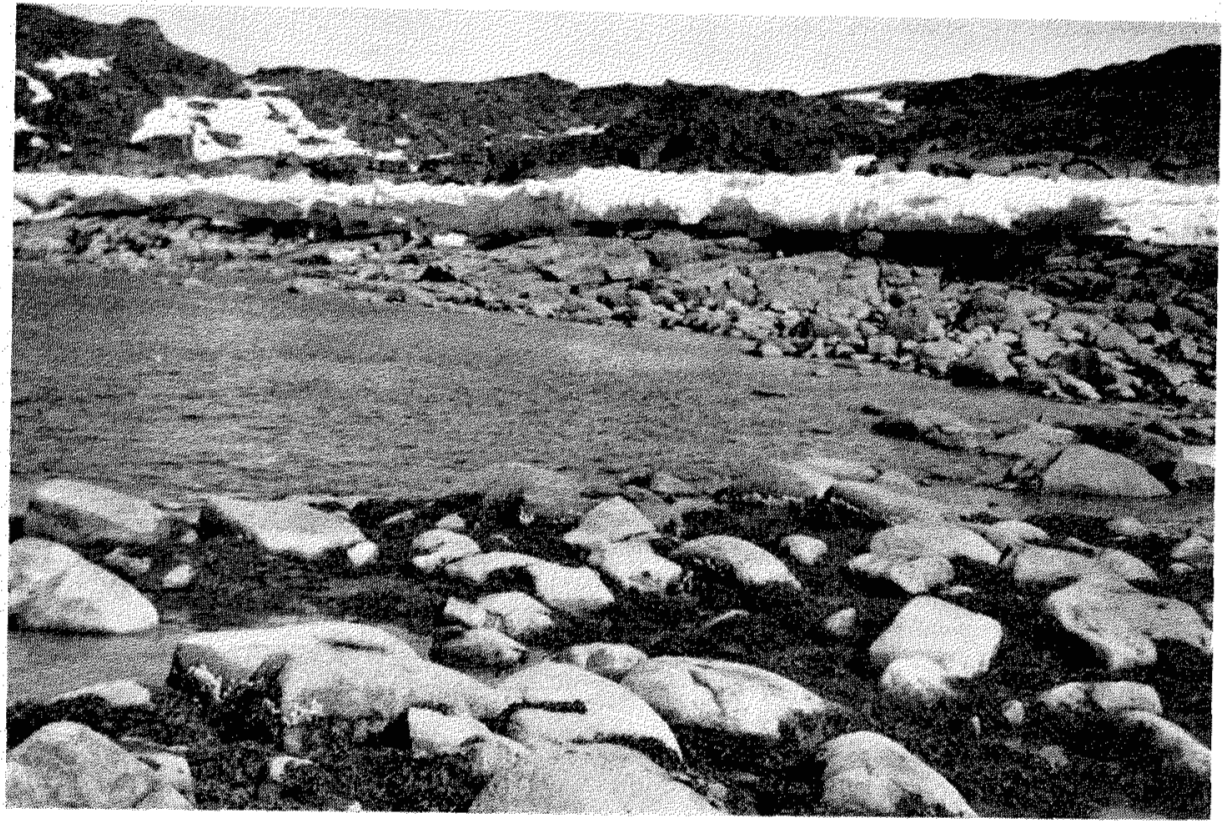

Fig. 8. Beach in Frobisher Bay, Station A8, with 35-foot tidal range. The algae and barnacles in the foreground are kept off the upper parts of the boulders by ice action. Some ice is still stranded on the upper levels of the beach.

The unpublished oceanographic data on sea temperature and salinity from the Calanus expeditions to Frobisher Bay and Cumberland Sound suggest that these regions may be influenced by the warm currents flowing west from Greenland (Canada. Fish. Res. Bd., 1953), unlike the sea-water farther north. The northern limits of B. balanoides, L. saxatilis and A. marina occur at Upernavik and Angmagssalik in west and east Greenland, where the influence of Atlantic water has been demonstrated. Recent collections from Baffin Island indicate that the northern limits of these species on the east coast may coincide with the northern limits of non-polar water.

The distribution of specifically intertidal animals in southeast Baffin Island may reflect a change in the nature of the sea-water related to the underlying currents. If this is so, Madsen's hypothesis that the intertidal population is influenced by the currents, will be valid for the east Baffin Island coast. It thus seems that the marine arctic and subarctic regions in Baffin Island and Greenland differ in their intertidal populations. In the subarctic region there are marine animals specifically adapted to living on the shores; these species do not extend into the arctic region. In places protected from ice action the subarctic shores in Baffin Island support a fauna and flora. The arctic shores, however, are almost barren because ice covers almost the whole intertidal region during winter; a surface layer of very low salinity water presumed to occur in summer prevents the shallow-water pan-arctic species from settling on the shore; and pure polar water prevents the northward distribution of the 
specifically intertidal species. North of Cumberland Sound the three factors come into operation simultaneously. They do not do so in east Greenland, for the specifically intertidal species are found at Angmagssalik, where the shallow-water species are kept below the surface layer of "fjord-water". Madsen reports that the tidal range does not vary much along the east Greenland coast, and cannot therefore be responsible for limiting the northward distribution of the intertidal species. The tidal amplitude alone means very little. It is the relationship between the depth of ice formed in winter, the extent of the "fjord-water" layer, and the tidal amplitude that is important. Where the shore is partly unaffected by ice and bathed in water of sufficiently constant salinity, the panarctic species will populate the shores regardless of whether they are in the arctic or subarctic regions. They can rarely do so in the arctic region because of the low tidal amplitude and the extensive development of "fjord-water".

It is, therefore, clear that there are two intertidal transitions, one which affects the panarctic shallow-water species, and the other the specifically intertidal species. The two transitions coincide in Baffin Island; they do not coincide in east Greenland. Once the panarctic species that are limited vertically by ice and low salinity are recognized, the northern limit of the subarctic in Baffin Island appears to coincide with the northern limit of the specifically intertidal species.

This research was financed by a McGill University-Arctic Institute Carnegie scholarship. It could not have been undertaken without the assistance of the following people and organizations, for which I am deeply grateful: Professor V. C. Wynne-Edwards for his help during the summer; Dr. M. J. Dunbar, McGill University, for his advice while identifying the specimens; the Atlantic Biological Station for assistance in preparing for the collections; Dr. E. Grainger for identifying the polychaete worms; the personnel of the Hudson's Bay Company, the Royal Canadian Mounted Police, the Royal Canadian Air Force, and several Eskimo in Baffin Island.

\section{References}

Bertelsen, E. 1937. 'Contributions to the animal ecology of the fjords of Angmagssalik and Kangerdlugssuak in east Greenland'. Medd. om Grónl. Vol. 108, No. 3, $58 \mathrm{pp}$.

Canada. Fisheries Research Board. 1953. "Eastern Arctic investigations". Ann. Rep. 1952, pp. $149-54$.

Canada. Hydrographic Service. 1953. 'Atlantic coast tide and current tables 1954'. Ottawa: 145 pp. (Tidal Publications No. 1).

Dall, W. H. 1924. 'Mollusks, Recent and Pleistocene'. Can. Arctic Exp. 1913-1918, Rep., Vol. 8, Pt. A, 29 pp.

Dunbar, M. J. 1951. 'Eastern Arctic waters'. Fish. Res. Bd. Can. Bull. No. 88, 131 pp. 1953. "Arctic and subarctic marine ecology: immediate problems". Arctic, Vol. 6, pp. 75-90.

Ekman, S. 1953. 'Zoogeography of the sea'. London: $147 \mathrm{pp}$.

Hancock, A. 1846. 'A list of shells dredged on the west coast of Davis's Strait'. Ann. of Mag. Nat. Hist. 1st Ser., Vol. 18, pp. 323-38. 
Kiilerich, A. B. 1939. 'The Godhaab expedition 1928. A theoretical treatment of the hydrographical observation material'. Medd. om Gronl. Vol. 78, No. 5, 149 pp.

Kumlien, L. 1879. 'Contributions to the natural history of arctic America made in connection with the Howgate Polar expedition 1877-78'. U.S. Nat. Mus. Bull. No. 15, $179 \mathrm{pp}$. (Also issued in Smithsonian Misc. Coll. Vol. 23).

Lemche, H. 1941. 'The zoology of East Greenland. Gastropoda Opisthobranchiata'. Medd. om Grønl. Vol. 121, No. 7, 50 pp.

Madsen, H. 1936. 'Investigations on the shore fauna of east Greenland with a survey of the shores of other arctic regions'. Medd. om Grønl. Vol. 100, No. 8, $79 \mathrm{pp}$.

1940. 'A study of the littoral fauna of north-west Greenland'. Medd. om Gronl. Vol. 124, No. 3, 24 pp.

Pfeffer, G. 1886. "Mollusken, Krebse und Echinodermen von Cumberland-Sund . . .". Jabrb. Hamb. wiss. Ans. Vol. 3, pp. 23-50.

Rae, R. W. 1951. 'Climate of the Canadian Arctic Archipelago'. Toronto: $90 \mathrm{pp}$.

Riis-Cartsensen, E. 1931. 'The Godthaab expedition 1928. Report on the expedition' Medd om Grónl. Vol. 78, No. 1, 105 pp.

Smith, E. H., F. M. Soule, and O. Mosby. 1937. 'The Marion and General Greene expeditions to Davis Strait and Labrador Sea under the direction of the United States Coast Guard 1928-1931-1933-1934-1935. Scientific Results Pt. 2 Physical Oceanography'. U.S. Treasury Dept. Coast Guard Bull. No. 19, 259 pp.

Stephenson, T. A. and Anne Stephenson. 1949. "The universal features of zonation between tide-marks on rocky coasts". J. Ecol. Vol. 37, pp. 289-305.

1954. "Life between tide-marks in North America: IIIA Nova Scotia and Prince Edward Island: description of the region". J. Ecol. Vol. 42, pp. 14-70.

Steven, D. 1938. "The shore fauna of Amerdloq Fjord, West Greenland". J. Anim. Ecol. Vol. 7, No. 1, pp. 53-70.

Thorson, G. 1933. 'Investigations on shallow water animal communities in the Franz Joseph Fjord (East Greenland) and adjacent waters'. Medd. om Gronl. Vol. 100, No. 2, $70 \mathrm{pp}$. 